\title{
Political Government and Economic Government in J.R. Commons' Institutional Economics
}

\section{Kota Kitagawa}

\section{(2) OpenEdition \\ 12 Journals}

Electronic version

URL: http://journals.openedition.org/ei/5916

DOI: $10.4000 /$ ei.5916

ISSN: 2553-1891

Publisher

Association Économie et Institutions

Electronic reference

Kota Kitagawa, «Political Government and Economic Government in J.R. Commons' Institutional Economics», Économie et institutions [Online], 26 | 2017, Online since 01 July 2018, connection on 19 April 2019. URL : http://journals.openedition.org/ei/5916 ; DOI : 10.4000/ei.5916

This text was automatically generated on 19 April 2019

Revue Économie et institutions 


\title{
Political Government and Economic Government in J.R. Commons' Institutional Economics
}

\author{
Kota Kitagawa
}

This article was supported by JSPS KAKENHI (Grant-in-Aid for Early-Career Scientists) Grant Number JP18K12753.

\section{Introduction}

1 This research project for constructing "monetary institutionalism" began in the Frenchspeaking world. At a session of the opening conference for the project, we attempted to uncover the "unacknowledged institutionalist antecedent" (Baslé 2002), John Rogers Commons (1862-1945) (Dutraive \& Théret 2016; Nakahara \& Uni 2016). His work on money is either unknown or known only superficially by modern institutionalists. However, both his practice and research work strongly concerned money (Commons 1934a). For instance, he presented the novel idea of the governance system of the Federal Reserve Board (FRB) to the Committee on Banking and Currency in the House of Representatives (Commons 1928a). About 260 pages out of the 921 pages of his masterpiece Institutional Economics were devoted to a discussion of money as an evolving "social institution" (Commons 1934b, chapter IX "Futurity"). Nevertheless, a few previous studies have compared his theory of money to that of Keynes, and classified it as "Post-Keynesian Institutionalism" (Atkinson \& Oleson, 1998; Tymoigne 2003; Whalen 1993, 2008, p. 232). Yet the main characteristic of his theory is the "evolutional" perspective for discussing institutions. Only Dutraive and Théret $(2013,2017)$ discussed money as an institution from the evolutionary perspective.

2 According to their original dichotomy of "political sovereignty" and "monetary sovereignty," Dutraive and Théret (2017) developed "two models" to describe the evolution of monetary institutions based on Commons' works. The two models differ in the relationship between political and monetary sovereignties. "In the first model, 
monetary sovereignty is owned by private banks and is potentially in competition with political sovereignty. In the second model, money can be viewed as an agent of political sovereignty, which shares some similarities with the law as an institution of sovereignty in the modern state" (Dutraive \& Théret 2017, p. 27).

This study reveals the evolutionary nature of monetary institutions found in Commons' works using the groundwork developed by Dutraive and Théret (2017), while at the same time, offers its critique. I revise their work from the following three aspects. First, Dutraive and Théret (2017) used their original terms "political and monetary sovereignties," in order to develop the two relationships described above from Commons' works. I reinterpret the evolution of money as an institution based on Commons' own terms and descriptions. Dutraive and Théret (2017) equated "political sovereignty" to Commons' term "sovereignty." However, is there a term in Commons' works compatible with their term, "monetary sovereignty?" I argue that monetary sovereignty and its supreme power correspond to "an economic government of bankers" and its "economic power" as used by Commons (1934b, p. 895). Economic power is defined as "the power of withholding property rights from others as a means of commanding obedience" (Commons 1950, p. 75). The term I contrast with "economic government" is "political government" (Commons 1929, 1934b, p. 895). While Dutraive and Théret (2017) derived their comparison between political and monetary sovereignties from Commons (1934b), I base my comparison directly on Commons' (1934b) literature.

4 Second, although they continue presenting the two relationships between political and monetary sovereignties as two models, I see the "mutual dependence" and "conflict" in the two "principles" (economic principle: "scarcity" and ethical principle: "reasonableness") included in the models (Commons 1934b, p. 80, p. 341; Dutraive \& Théret 2017, p. 35), as driving forces of institutional evolution.

Third, in the interpretation of institutional evolution, I replace the "advisory committee," which Commons recommends as the monetary governance system. The advisory committee is a collegial body consisting of representatives of organized economic interests. Its rules have the same status as laws, which it administers, and disputes are resolved under its jurisdiction. Conflicts of economic interests are resolved through negotiations and compromises in the rule-making processes. Dutraive and Théret (2017) place this in their "second model," guided by ethical principles. However, this placement involves the risk that the advisory committee is reduced to a merely moralistic proposition. Yet, the dichotomy of political and economic governance is useful when we think of the significance of his proposition of an advisory committee. From the perspective of this dichotomy, we will be able to understand that his proposition of a governance system considers not only the principle of political government but also that of economic government.

6 Finally, this paper is constructed as follows. In the next section, I define the terms used in this paper that conform to Commons' own terms. In particular, the main issues are "political government" and "economic government." In section 2, I show how the political (federal-level, state-level) and economic governments relate to each other in the evolution of a political economy. First, I address the relationship between sovereignty and the pay community in the evolution of a political economy (Section 2.1). Since "a pay community is the concerted action of creditors and debtors in setting up a procedure for the release of debts" (Commons 1934b, p. 457); in modern capitalism, it is embodied by bankers. I present the evolution of a political economy as a process in which sovereignty 
regulates the pay community, seen as a private business practice. Sovereignty regulates the pay community following ethical principles; that is, a code of public purpose(s). The public purposes presented in Commons (1934b) are three necessary conditions for "reasonableness" of transactions-equal opportunity, fair competition, and equality of bargaining power. I recognize this evolution as the progression towards a reasonable capitalism. However, Commons (1934b) saw the evolution of political economy from the point of view of bankers. In other words, Commons (1934b) explained such an evolution as a process whereby bankers accumulate economic power (this behavioral principle is "scarcity;" that is, the economic principle) using the legal foundations of sovereignty (Section 2.2). The discussion of this evolution in Commons (1934b) implies that the economic government, resulting from an alliance between the pay community (the bankers) and industry, will end up controlling the political government (Commons 1934b, p. 773). In section 3, I take the relationships of political and economic governments abstractly confirmed in section 2, and identify them as the parallel relationships of "mutual dependence," "conflict," and "politics." These relationships are the driving forces of institutional evolution. In section 4, I interpret the advisory committee from the perspective of the dichotomy of political and economic governments. As a result, from the perspective of the dichotomy of political and economic governments, we understand that Commons' proposition concerns both ethical and economic principles. In conclusion, I stress that his proposition of the governance system of money as institution may be useful even today.

\section{Definitions of Sovereignty and Economic Government}

In this section, I address three issues. First, I clarify Commons' (1934b) definition of "sovereignty" as that of "political sovereignty," as used by Dutraive and Théret (2017). Second, I search for terms in Commons (1934b) that are compatible with "monetary sovereignty" and the sovereign power of money found in Dutraive and Théret (2017).

In Commons (1934b), Commons defines "sovereignty" as follows:

Sovereignty is the extraction of violence from private transactions and its monopolization by a concern we call the state. But sovereignty has been looked upon as an entity as well as a process. As an entity it is personified as The State, and seems to exist apart from the people. As a process it is the extraction of the sanction of violence from what had been considered to be a private affair, and the specialization of that sanction in the hands of a hierarchy of officials guided by working rules and habitual assumptions. Sovereignty, thus, is the changing process of authorizing, prohibiting, and regulating the use of physical force in human affairs.

(Commons 1934b, p. 684)

9 Thus, the definition of sovereignty in Commons (1934b) has two aspects. The first aspect is the monopoly of physical power. ${ }^{1}$ This is the power to define rules (constitutions, statutes, legal precedents, etc.) and enforce these rules (court decisions, administration, etc.). In this aspect, sovereignty is seen as an entity; that is, a government. The second aspect is the monopolization of physical power. This implies that sovereignty is seen as a dynamism or evolving process of governing the sovereign power, or violence. Commons described that the government had evolved from "executive sovereignty" to "legislative sovereignty" to the current U.S. form, "judicial sovereignty" (Commons 1934b, 
p. 684-685). In the last form, the U.S. Supreme Court holds the sovereign power because it is authorized to determine the constitutionality of legislation according to ethical principles; that is, the pursuit of "reasonableness." The elements of reasonableness of economic transactions are equal opportunity, fair competition, and equality of bargaining power. The meanings of these words have been changed and will be changed by decisions of the Supreme Court, which makes decisions pragmatically, according to its precedents and the changing economic situation (Kitagawa 2017).

Money is not related to this definition of sovereignty. Next, I examine the concept of money as referred to by Dutraive and Théret (2017), and search for a corresponding word in Commons (1934b). Dutraive and Théret said:

Our interpretation is that, for Commons, money is an institution that directly participates in the development of modern sovereignty. Thus, money can be considered a component of government in society, whose power is another form of sovereignty, as in the case of judiciary power. However, in its contemporary form of banking and credit relationship, the monetary institution and its working rules can be influenced by cohesive groups affiliated with the banking and financial system, possibly in opposition to political sovereignty. (Dutraive \& Théret 2017, p. 28)

11 Dutraive and Théret (2017) referred to "sovereignty" as something that holds supremacy, and is in the position of mediating social relations. The source of the sovereign power of money is the fact that each individual is subject to two money-based pressures. First, market participants who disagree with the unit of currency are exposed to pressure to leave that particular market. Second, market participants who disagree with the rules regulating the use of money also receive pressure to leave the market.

We can find a term in Commons (1934b) corresponding with this normative power described by Dutraive and Théret; it is "economic sanction" or "economic power." In Chapter IX of Commons (1934b), Commons inquires, in certain communities, what powers make demand-debts of a bank the instrument that releases debt. His answer is that the powers are not only sovereign powers, to which Knapp's "state theory" of money is limited, but also "the economic sanctions" of this private pay-community. If a business person refuses to accept the demand-debt, which is customary tender, the person must be excluded from the bargaining transactions in the business community, namely the paycommunity. He does not stress a voluntary choice of individuals, but strongly stresses the collective compulsion of a private community.

It is not only a matter of convenience with him, nor only a voluntary choice of alternatives, nor only the expectation that he in turn as a debtor can also pay his own debts with the same or equivalent bank checks, nor the expectation of redemption in legal tender it is a matter of economic compulsion. It is the economic sanctions of competition, ending in profit or loss, success or bankruptcy, that enforce acceptance of the customary tender of bank checks. So that ultimately nine-tenths of the debt payments in the United States are accomplished, not by legal tender, but by customary tender.

(Commons 1934b, p. 461-462)

13 Commons (1934b) argued that, due to this economic power (economic sanctions), money as used in the modern banking system represents the sovereign position, which is expressed by Dutraive and Théret (2017) with the term "monetary sovereignty." As previously discussed, Commons (1934b, p. 684) perceived sovereignty as the monopoly of physical power, or "the specialization of that sanction in the hands of a hierarchy of officials." With respect to economic power, Commons (1934b) discussed its "entity" and "process," which correspond to the entity that monopolizes physical power and the 
process of specialization of that power, respectively. "An economic government of bankers" that de facto controls certain industries corresponds to the entity of sovereignty, the monopoly of physical power, and, according to Chapter XI of Commons (1934b), to the process in which "the alliance of banking and industry" specializes and exerts its economic power (Commons, 1934b, pp. 891, 895; see section 2). The economic government referred to in Chapter XI of Commons (1934b) is the nexus between the pay community and "big businesses" (Commons 1934b, p. 888):

It is not needful for American capitalism to combine all competitors in a single holding company. It is only needful to combine the strongest companies and the strategic companies. These include the companies that own the natural resources, the companies that do the intermediate manufacturing and transportation, the companies that own trade-marks, good-will, and patents which furnish access to the patronage of customers, and the great bankers who finance the company. This is Integrated Capitalism, or Banker Capitalism, because the integration can be financed only by bankers.

(Commons 1934b, p. 895)

"Integrated capitalism" is the economic government of bankers. The economic government is compared to sovereignty, that is, the "political government" (see also Commons 1929, 1950, p. 74). The economic government's "sanctions are not the physical force of the state-they are more powerful sanctions of credit, profit, and loss" (Commons 1934b, p. 895). Hence, Commons (1934b) considered the economic government superior to the political government.

15 The behavioral principle of the economic government, compared to the ethical principle of the political government is the economic principle, or "scarcity." This principle is the obsession with monopolizing economic power to stabilize the market where the economic government exists, and to acquire more "expected margins for profit" (Commons 1934b, p. 580). The expected margin of profit refers to profit margins on sales, or on loans from the next turnover in the creation, negotiation, and release of debt. ${ }^{2}$

16 Table 1 displays some terms used by Dutraive and Théret (2017) and the corresponding terms in Commons (1934b). Studying the use of such terms in Commons (1934b), especially the contrast between sovereignty and the private pay community, or between political government and economic government, we realize how the dynamics of sovereignty and the pay community are discussed in Commons (1934b). 
Table 1. Correspondence between the terms used by Dutraive and Théret (2017) and those in Commons (1934b)

\begin{tabular}{|c|c|c|c|}
\hline \multicolumn{2}{|c|}{$\begin{array}{c}\text { Terms used by } \\
\text { Dutraive and Théret (2017) }\end{array}$} & Political sovereignty & $\begin{array}{l}\text { Monetary sovereignty } \\
\text { (Economic sovereignty) }\end{array}$ \\
\hline \multirow[t]{4}{*}{$\begin{array}{l}\text { Corresponding } \\
\text { terms in Commons } \\
(1934 b)\end{array}$} & Entity & $\begin{array}{l}\text { Political government } \\
\text { (sovereignty) }\end{array}$ & $\begin{array}{l}\text { Economic government } \\
\text { (the alliance of banking and } \\
\text { industry) }\end{array}$ \\
\hline & Process & $\begin{array}{l}\text { The monopolization of } \\
\text { violence in the hands of a } \\
\text { hierarchy of officials }\end{array}$ & $\begin{array}{l}\text { The creation of a nexus, } \\
\text { supported by bankers, that } \\
\text { can control a certain industry }\end{array}$ \\
\hline & Power & $\begin{array}{l}\text { Physical power: violence } \\
\text { (Sovereign power) }\end{array}$ & $\begin{array}{l}\text { Economic power } \\
\text { (Economic sanctions) }\end{array}$ \\
\hline & Principles & $\begin{array}{l}\text { Reasonableness } \\
\text { (Making legal foundations of } \\
\text { equal opportunity, fair } \\
\text { competition, and equality of } \\
\text { bargaining power in private } \\
\text { transactions) }\end{array}$ & $\begin{array}{l}\text { Scarcity } \\
\text { (Collecting economic power } \\
\text { to stabilize the condition of } \\
\text { the market to which one } \\
\text { belongs and acquire greater } \\
\text { profit margins) }\end{array}$ \\
\hline
\end{tabular}

Source: Compiled by the author

\section{Political Government and Economic Government}

\subsection{Sovereignty and the Evolution of the Pay Community}

In Commons (1934b), "money" is a means of payment ("means of release") for debts, and a unit of measurement ("unit of validity," "unit of value") for the size of the debt. ${ }^{3}$ A pay community follows rules that consist of business customs and laws. Private and public rules represent the legal foundation for money to be both a means of payment and a unit of measurement. Commons (1934b) also saw money as a "social institution" (Commons 1934 b, p. 513), which means that the debt system itself is supported by these customary and legal rules.

18 The aforementioned rules have evolved over time. Debt has changed from unnegotiable to negotiable debt, and from "unreleasable" to "releasable" debt (Commons 1934b, p. 390). The "negotiability" of debt was established by decisions of the court of equity, which assumed the doctrine of assumpsit from established business customs practiced by merchants and manufacturers (Chapter VII in Commons, 1924). The court's decision guaranteed the "incorporeal property" created by oral contracts. The amount of releasable debt expanded through the abolition of slavery, bankruptcy laws, "the gradual abolition of term or life contracts for labor by substituting contracts 'at will," and "the prohibition of truck payments and substitution of money payments" in the case of wages (Commons 1934b, p. 458).

19 It should be noted that, in most cases discussed by Commons, the origin of legal precedents and statutes were business customs. The legal foundations of the private pay 
community descend from two groups of rules: private rules (which are generated and changed by the pay community itself) and public rules (which are established and amended by the political government, with reference to the private rules). The pay community of modern capitalism, having descended from both private and public rules, is described as a "transactional system of money and value" (Commons 1934b, p. 510). When money is an institution, a unified "unit of measurement," the value of debt, is created, negotiated, and released. These three steps represent a "turnover." Each turnover is repeated at a certain speed ("velocity" of turnover), which varies over time. Commons' (1934b, p. 510) "transactional system of money and value" consists of repeated commodity transactions and repeated debt transactions.

Our formula of a turnover of bargaining transactions [that consists of two buyers and two sellers] has not hitherto included the banker. Yet all modern transactions require the participation of bankers. Even the "cash" payments, usually termed the "circulation of money," consist in drawing cash from the banks instead of transferring demand debts at the banks. This cash again "flows" into the banks in payment of debts owed to the banks. The banks themselves, if short on this "money in circulation," call upon the Reserve banks for "money," thus reducing their balances at the Reserve banks. Or, if long on circulation, they return their "cash" to Reserve banks in order to pay debts to the Reserve bank and thus augment their Reserve balance.

Hence each of the two buyers and two sellers of a bargaining transaction, who make the whole of the debt-payments, must have not only an account at his bank, but also an understanding with the banker as to what he may expect towards obtaining the means of payment, which the banker will himself create as a deposit for carrying out transactions.

Thus our formula for a complete bargaining transaction must have four bankers, one for each of the two buyers and two sellers in the transaction. (Commons 1934b, p. 510)

Short-term commercial debt is issued as a result of commercial transactions between a buyer and a seller in a commodity market. A banker accepts the commercial debt at a discounted value, and at the same time, creates a debt payable on demand in the seller's commercial account of the bank. The seller uses the created "money," and pays the seller's own debts for wages and raw material costs.

Thus each loan transaction creates its own money. There is not a fund of money that "circulates, " but there is a repetition of the creation, sale, and payment of short-time debts to the amount equivalent to the discounted values of the titles of ownership alienated. Two succeeding increases in value thus occur, based on forecasts of the prices of commodities: the increase in output of use-value of commodities to be added by the input of labor; and the increase in value of the discounted debt as it approaches maturity.

(Commons 1934b, p. 511)

21 In Figure 1, I schematically illustrate a bargaining transaction. ${ }^{4}$ Commodities represent one side of the bargaining process, and the other side illustrates the creation of debt. Bankers, whose customers are buyers and sellers, are responsible for the creation of debt. Money (referred to as debt, in Commons 1934b) is not introduced in the market exogenously from the Federal Reserve System, but endogenously, through the credit requirements of myriad bargaining transactions in the commodity market. Credit requirements reflect a businessperson's motives for purchases and his/her appetite for investment. Further, credit requirements often depend on the profit margins of his/her business. In this way, one's profit margin is the key piece of information associated with a businessperson's decision-making. ${ }^{5}$ 
All participants in the bargaining transaction represented in Figure 1 are involved in both the commodity and debt markets. $\mathrm{B}$ and $\mathrm{B}^{1}$ in Figure 1 represent two of the 48 million buyers in the debt system of Figure 2; $\mathrm{S}$ and $\mathrm{S}^{1}$ represent two of the 48 million sellers. Banker ${ }^{\mathrm{B}}$, Banker ${ }^{\mathrm{B} 1}$, Banker ${ }^{\mathrm{S}}$, and Banker ${ }^{\mathrm{S1}}$ represent four of the 9,000 member or nonmember banks. Bankers act concertedly, in accordance with the provisions of the Federal Reserve System.

Figure 1. A bargaining transaction involving nine parties

\section{Sovereignty (Courts, federal legislature, state legislatures)}

Issue: Are ethical principles (equal opportunity, fair competition, and equality of bargaining power) accomplished in this transaction?

Regulation by decisions, legal precedents, statutes $>$

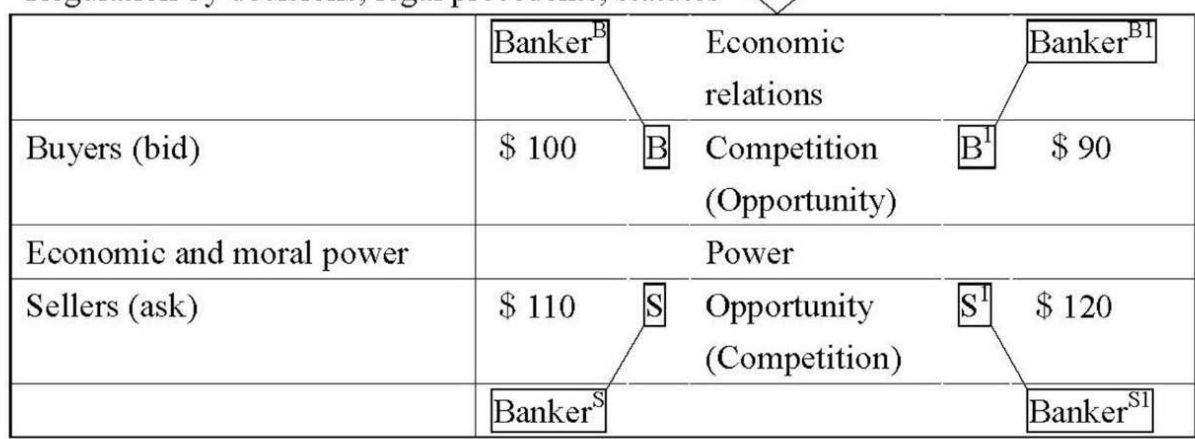

Source: Compiled by the author, based on Commons (1927, chapter I, sheet 15) and Commons (1928b, reel 12, sheet 762)

How does sovereignty relate to the turnover of bargaining transactions (i.e., the creation, negotiation, and release of debt)?

Legal analysis resolves negotiation between participants of a transaction into persuasion or coercion, fair or unfair competition, equal or unequal opportunity, reasonable or unreasonable price, all of them dominated by scarcity, expectation, and the customary and legal rules of the time and place. Then if these conditions of persuasion, fairness, equality and reasonableness are not met, or disregarded, the court, representing the collectivity, reads into the negotiations, which creates a debt, determined and measured by the [...] dimensions of the value.

(Commons 1934b, p. 524-525)

Thus, if the court observes inequality, unfairness, and unreasonableness in a loan transaction, it corrects the situation. In a court decision regarding a loan transaction, the court compares the loan transaction in question with other "ordinary" and "customary" loan transactions in similar situations of the same period. The "reasonable" transaction in the court's decision means it is considered an "ordinary" and "customary" transaction. Since the meaning of "ordinary" and "customary" practices change gradually, the meaning of "reasonable" practice is also gradually changed by court decisions. 
Figure 2. The Debt Market. Credits and Debits as of June 1929

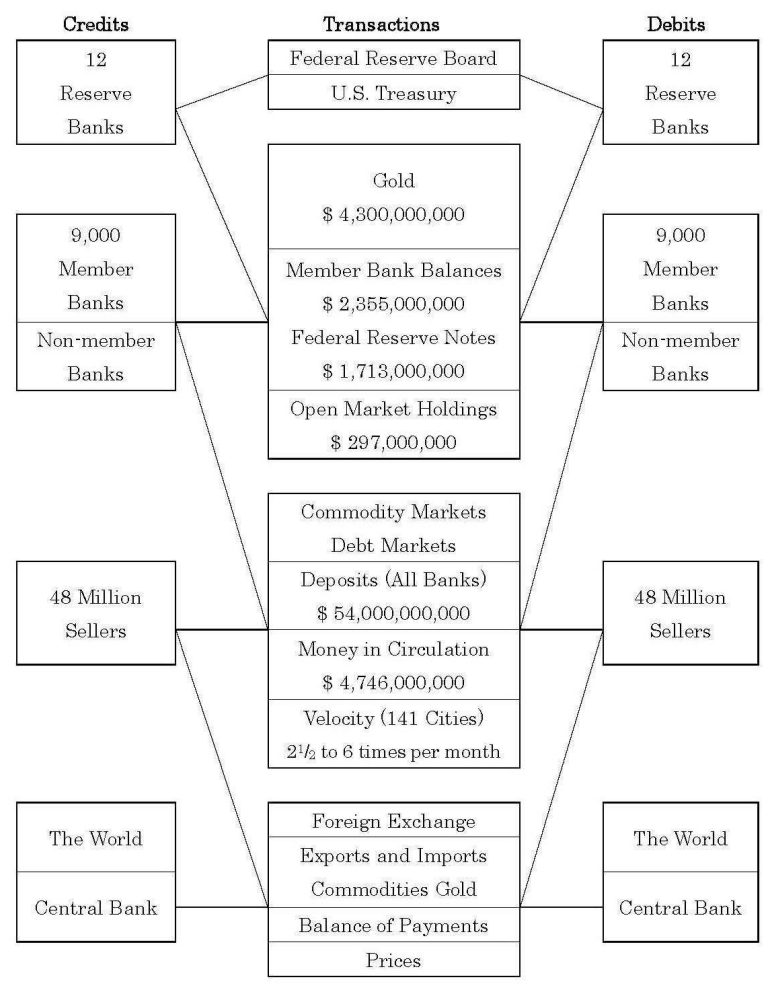

Source: Commons (1934b, p. 396, Chart 6)

Federal and state legislatures complement the court decisions, being the legal foundations for the turnover of bargaining transactions. I present two examples below. The first is the "small loan law," which:

created licensed companies authorized to charge, on sums of $\$ 300$ or less, a rate of 3 $1 / 2$ per cent per month, or 42 per cent year, on unpaid balances, and making illegal any rates on small loans in excess of that rate. This law was adopted by a number of states. It was their standard of the reasonable value of the service rendered by loan companies to necessitous small borrowers. Here it is that organized society attempts to offer to the necessitous borrower an alternative, which its spokesmen, the legislature, deem reasonable.

Yet, on first impression the states were legalizing an usurious rate of interest. But, considering the only alternatives previously available to this class of borrowers who were unable to borrow at commercial banks at the usual legal rates of interest, a rate of $3{ }^{1} / 2$ per cent per month would have been approximately 32 cents.

(Commons 1934b, p. 335)

This is a case of correction of unequal opportunity. The starting point of the court's (and Commons') inquiry is not an ideal market, but a real situation. In an ideal market, there are possible newcomers who will compete with existing market participants, and if the rate is high, the newcomer enters the loan market and lends to borrowers at a lower rate. However, in a real loan market, newcomers are restricted for certain reasons, and the rate remains high. An individual who has less bargaining power than a corporation is forced to borrow from a banker at a high rate. In this situation, the borrower's opportunity is unreasonable. This small loan law - a state law - restrains the bargaining (economic) power of bankers. This law compares the bargaining power of a weak 
borrower and a strong borrower, such as a corporation, and corrects the unequal bargaining power and unequal opportunity.

The second example is the Federal Reserve System, established in 1913. This system integrates thousands of banks, and takes concerted actions with respect to interest rates and supplied amounts of credit. ${ }^{6}$ The reasons for the creation of this large system include the equalization of bankers' bargaining power, and the stabilization of prices and employment.

Manufacturing industries next [to labor organizations, railways, and public utilities] came within the theory [of reasonable bargaining power], the issue, in their case, culminating in the [1920 U.S. Steel dissolution] cases [...]. Then the most comprehensive of all industries, the banking industry, was admitted to the process [of the historical expansion of the theory of reasonable bargaining power], under the Federal Reserve Act which authorized concerted action of eight thousand banks [that increase to nine thousand banks in at June 1929], guided by twelve Reserve banks, in regulating the prices to be charged for, and the volume to be issued of, bank credit.

(Commons 1934b, p. 345-346)

The operations of the Federal Reserve System reflect the concerted actions of myriad bankers, buyers, and sellers. Commons envisaged the creation of a worldwide system of concerted actions of central banks deciding their rates; he refers to this system as the "world pay community" (Commons 1934b, p. 590). Inspired by Wicksell's suggestion (Wicksell 1898), Commons highlighted the importance of the world pay community, but he was not optimistic about the actual creation of such an international community:

At this writing, in November 1933, the nations have definitely failed to get together on all questions of national and international conflicts of interests, whether economic, monetary, or military, and the future is unpredictable. (Commons 1934b, p. 611)

In summary, Commons perceived the change driven by sovereignty and the pay community as the process whereby sovereignty provides the legal foundation to create, negotiate, and release debt to the pay community. This is a process in which sovereignty regulates the pay community, which was created through business customs, and is in line with public purposes. We see this evolution as a process toward reasonable capitalism.

\subsection{Sovereignty and Formation of the Economic Government}

In contrast with the process toward the satisfaction of public needs, in Chapter IX, Commons (1934b) outlined the process where bankers, symbolizing the pay community, build an economic government through a concentration of economic power. The formation of the economic government implies the alliance between bankers and industrial corporations. Before discussing such alliance, however, it is necessary to address how sovereignty affects corporations.

31 Sovereignty gave a legal foundation to corporations almost in the same way as in the evolution of the pay community. The key concept is "incorporation." In the U.S.'s early days, only "those which received special charters by act of legislature" became corporations (Commons 1934b, p. 881). "In order to get a charter of incorporation the business men had to align themselves with the politicians" (Commons 1934b, p. 881). At this stage, those with political power took control, as mediators between political parties and capitalists. However, "in order to get rid of political corruption," state legislatures 
introduced general corporation laws, starting with the state of New York, in 1848. Corporations "established a new right of business men-the right of association" (Commons 1934b, p. 881).

Then came a new discovery, thirty years ago, the holding company, invented by the corporation lawyers to evade the anti-trust laws, and enacted first by the legislature of New Jersey. It was not altogether new, for corporations could always own the stocks and bonds of other corporations. Its novelty consisted in creating corporations solely or mainly for the purpose of owing and voting the stocks of other corporations. Other states competed with New Jersey for this profitable business.

Almost unlimited powers were granted to the holding companies, and they had all the privileges in other states which they had in their own state. The only restraint upon them now became the Supreme Court of the United States. (Commons 1934b, p. 882)

Based on a "per se illegal rule" (any accused, concerted action restricting transactions was illegal), the Supreme Court introduced antitrust laws. In 1911, the Supreme Court disbanded two holding companies, Standard Oil and American Tobacco. However, the Supreme Court, a judicial sovereignty, had exercised its sovereign power strictly to maintain free competition until the 1910s. In the 1920 U.S. Steel dissolution case, the Supreme Court applied a new criterion for judgment, the "rule of reason." This rule assumes that public interests must be weighed against the observed and potential disadvantages of competitive restrictions. As a consequence, restrictions toward holding companies with considerable economic power were softened. Sovereignty provides legal foundations for corporations to exercise their economic power, while sanctions against corporations are enforced only when their actions have a negative impact on public interests.

Large corporations were forced to depend on bankers to raise large amounts of capital. Bankers formed alliances within certain industries, like big manufacturing corporations at the top of an industry, attempting to control them through funding and dispatching executives. A symbolic case of "the alliance of banking and industry" was the merger of Federal Steel (in which J.P. Morgan and E.H. Gary held large proportions of the stock) and Carnegie Steel, which was held by A. Carnegie (Commons 1934b, p. 890). U.S. Steel was established in 1901, funded by big bankers purchasing the capital of big capitalists (Chernow 1990). U.S. Steel was the first company in American history with capital exceeding $\$ 1$ billion. Commons discussed the American capitalism of big bankers and big manufacturing corporations as follows:

The United States Steel Company, created by a banker syndicate, and sustained by bankers, in some of its branches of manufacture controls less than half of the nation's output. But if a small competitor, in the stress of hard times and lack of orders, ventures to cut prices in order to pull customers away, a mere announcement by head of the [U.S.] Steel Company that it intends to "meet competition" brings the unruly competitor back to the prices set by the dominant corporation. [...] This is American Capitalism. It is an economic government of bankers more powerful than the political government. Its sanctions are not the physical force of the state-they are the more powerful sanctions of credit, profit, and loss. The system looks like the old "law" of supply and demand and like the economists' principle of marginal utility. Competition still is free, but the sanction has been changed from the economist's satisfaction of wants to the business man's fear of bankruptcy. The little capitalists [...] become in America the disciplined followers of Banker Capitalism.

(Commons 1934b, p. 895) 
economic government of bankers, however, means more than the concerted action of banking syndicates and big manufacturing companies. As pointed out in the quotation above, it also means explicit and implicit codes of conduct rooted in the "fear of bankruptcy." Small capitalists are inevitably involved in concerted actions based on these codes. Thus, the alliance between banking and industry exerts its economic power in a different way than a monopoly. With respect to the development of the alliance between banking and industry, a perspective that stresses the formation of a great power is different from one that stresses the restraint on the pay community through political government, to achieve public purposes (discussed in section 2.1).

can see a similar description of the Federal Reserve System. In section 2.1, I discussed Commons' view of a system established to achieve equality of bargaining power-a public purpose. Chapters VIII and IX in Commons (1934b), written in the period between 1927 and 1929 (Commons 1927, 1928b), reflect this view. In his writings after 1929, he emphasized how the political government gradually lost control of the economic government.

In the public interest and the need to economize the scattered gold reserves in order to furnish a flexible currency, the Congress unites the bulk of the banks in a great Federal Reserve System, like similar central banks of the world. The System makes its own rules and governs its members and borrowers, much like a trade union. The banking system the world over has become the head of the modern system of national and international economic government, not only because the banks sought aggrandizement for themselves but because dire public necessity required unity of operation in place of the older competitive individualism. Great industrial corporations are represented on the boards of directors of the twelve bank boards, and the alliance of banking and industry is complete.

Then the [political] government appoints a Federal Reserve Board to supervise this stupendous banker's [economic] government of its own creation, but with low salaries and insecurity of tenure in dealing with men of fabulous salaries and the shrewdest of ability which modern capitalism enlists in establishing its supremacy. (Commons 1934b, p. 890-891)

When the bankers reach the limit of their ability, as in 1932, then the [political] government itself organizes a huge reconstruction finance corporation to relieve the bankers of liability. Meanwhile central banks controlled by bankers rise to a new importance and Banker Capitalism comes into control of industries and nations. (Commons 1934b, p. 773)

Bankers had consolidated a significant economic power in their own hands, using not only industries, but also their physical power-the authority to construct and amend the legal foundations of the political government, which is founded upon law. In this way, it is possible to observe the consolidation of an economic power by the economic government. This process, as practiced by the economic government, can be seen in contrast to the process of monopolization of physical power, as practiced by the political government (see section 1). Commons (1934b) did not exemplify the lobbying of bankers. However, he viewed the political government as an entity, as well as the field of politicsthe internal activities of the political government. "Politics" in Commons (1934b) refers to the struggles of interest groups for power within the government. As one of the strongest interest groups, bankers are expected to affect the policy-making process. 


\section{The Relationships of Two Governments as Driving Forces of Institutional Evolution}

37 In the discussion on the origins and evolution of the pay community in section 2.1 (Chapters VIII and IX in Commons 1934b), I address the process whereby sovereignty restrains the pay community, in accordance with ethical principles. On the other hand, in section 2.2 (Chapters X and XI in Commons 1934b), which covers the relationship between the economic government (the alliance between the pay community and industry) and the political government (sovereignty), the economic government seizes a great economic power and starts to control not only small capitalists, but the political government as well, in accordance with economic principles. Dutraive and Théret (2017) drew the processes as "two models of the relationship" between political and economic governments. However, I want to go further by integrating the two parallel processes in the evolution of capitalistic institutions. This idea is based on the following two points. First, the two processes were presented in the same book, and were written by the same author-Commons. Second, the nature of Commons' institutional economics is an "evolutionary" one. Thus, I interpret that the constant change of the institution is driven by two forces, the political and economic governments.

In section 2, I discussed two processes. One of these is the process through which sovereignty coordinates the collective actions of thousands of bankers, which has enhanced the reasonableness of capitalism. The other process indicates that bankers increase their economic power by depending on legal foundations and making inroads in "politics" within the political government. The theory of institutional evolution brings the two processes together, and identifies two moving forces, one towards ethical principles and the other towards economic principles (often deviating from the ethical ones). Institutional evolution is constant and everlasting, since the two forces which relate to both "mutual dependence" and "conflict" are constantly in motion. Thus, I show three parallel circumstances that create dynamism-mutual dependence, conflict, and politics.

\subsection{Mutual Dependence}

While the behavioral principles of political and economic governments are different, they are in the relationship of "mutual dependence." The dependencies from political government to economic government are, for instance, the following two.

First, the political government get practical ideas of institutional reformation from the economic government. The political government has reformed institutions toward being "reasonable" by selectively authorizing certain business customs seen as "reasonable" by the political government-these customs spontaneously come into being in the economy. Therefore, the ideas of political government are not stored a priori in certain ideal public purposes or ethical principles but are created by the economy or novel practices of economic government. The point is that the political government is not the creator of institutions, but merely the volitional selector of institutional reformations; the political government depends on the economic government (or private pay community). 
41 Second, the policy tools of the political government have often been provided by the economic government. The political government created the system for stabilizing the debt market-namely, the Federal Reserve System ${ }^{8}$-by organizing the pay communities that had spontaneously developed. The origin of the financial policy device of the political government was constructed by the economic government.

In the same manner, the economic government also depends on the legal foundations provided by the political government. For instance, sovereign securities of incorporeal properties, expansion of releasable debt, and general corporation laws became the foundations for existence of the economic government.

43 Thus, the mutual dependencies of the political and economic governments enable the political government to reform institutions towards reasonable capitalism, and enable the economic government to exist and prosper.

\subsection{Conflict}

Conflicts happen because the principles of the political and economic governments are different. Two examples follow. The first is speculation and stabilization. The economic government is based on economic principles; if its expected profit margin is favorable, it behaves speculatively, using money financed by banks. The speculation of this debt money results in rapid shrinkage of credit, namely a crisis. From the perspective of stabilization, the political government has been required to prevent recurrences. The extreme case is the regulations of the debt market introduced in the New Deal era. The banking and securities industries were criticized by politicians and societies, as they were considered a culprit in the Great Depression. This strong pressure for reform tolerated even radical experimental policies aimed at overcoming the depression.

The second example is the conflict of the economic government's pursuit of monopolizing the market, and the political government's ethical principles (equal opportunity, fair competition, and equality of bargaining power). The decision of the Supreme Court of the United States in 1911 to liquidate one of dominant holding companies, Standard Oil, is a typical resolution of this conflict. However, the reasoning of the court in resolving that ideal conflict has evolved gradually, as confirmed in section 2.2. The operation of the anti-trust law then went into a slump, and in certain restrictions, "the alliance of banking and industry" was allowed to exist.

When I generalize in the above paragraphs, I can express the relationship of the two governments as follows. The economic government uses legal foundations, and creates novel practices for pursuing further profit margins and economic power. If the practices bring new economic problems, the federal or state congress initiates a rulemaking process in some cases. ${ }^{9}$ In other cases, when the novel practice creates problems in relation to existing business practices, and a suit regarding the novel practice is brought, the courts select a practice in line with its ethical principles. Since novel practices are constantly created, the legislation and selection are endless. The "cat-and-mouse game" of the economic and political government perpetuates institutional evolution. 


\subsection{Politics}

47 While mutual dependence and conflict are the relationships between political and economic governments, "politics" means "internal activity" within a government. The principle of politics is "the struggle for powers" (Commons 1934b, p. 761). When we see politics, we confirm that the principles of one government affect the other.

As is well known, the economic government participates in the internal activities of the political government to acquire further economic power. The typical case is lobbying and formation of pressure groups. Commons (1950) gives the example that the economic government requires jurisdiction over control of the debt system. Concerning the "lack of confidence" of capitalists in policies of Franklin D. Roosevelt, "the Board of Governors of the Federal Reserve System, the presidents of the Federal Reserve banks and the Federal Advisory Council, representing, as they do, banker control of the system, addressed the Congress of the United States in December 1940, recommending the abdication by Congress and the President of control of the credit system and favoring delegation of that control to this centralized organization of the Reserve banks of the country" (Commons 1950, p. 255-256). The economic government's "aggressive attitude" (Commons 1950, p. 256) thus conflicts with the intentions of the Congress and the president to retain their authority to stabilize markets.

From the standpoint of principles, ethical principles sometimes work in the internal activities of the economic government. Within the collective bargaining system between an employer and a trade union, the bargaining powers of the employer and the trade union are equalized. Welfare policies within big companies are established to gain the loyalty of the employees to the companies.

Although the ethical and economic principles are entangled in the internal activities, the dominant principle of the activities is "the struggle for power," or what is called "the political." The internal activities, or politics, make the relationship of the political and economic governments a nested structure. In other words, we can find economic principles in the political government and ethical principles in the economic government. The regulator of the opposing principles is, in this case, the political principle (the struggle for power).

\section{Advisory Committee: Boundary System of Political and Economic Governments}

51 Whalen (1993), after interpreting Commons' money theory from the Post-Keynesian perspective, discussed the advisory committee that Commons (1928a, 1950) presented as one of the "policy implications" of his money theory (Whalen 1993, p. 1165). However, that is not enough to help readers understand the significance of the advisory committee in the evolution of monetary institutions. Dutraive and Théret (2017, p. 42), referring to the description of Whalen (1993), placed the advisory committee in the model of "reasonable capitalism." However, this placement has a risk. Reader will see the advisory committee as merely a moralistic proposition by Commons. This study interprets the advisory committee as placed in the boundary area of the political and economic governments, and then shows that his proposition concerns both ethical and economic principles. 


\subsection{Developing the Boundary Area} government to transfer further authority over control of the debt system and deregulate it. The issue is, like the dichotomy we have used, whether the political or the economic government should administer the debt system.

In this conflicting context, Commons (1950, p. 254-257) proposed the advisory committee. It is a collegial body that consists of representatives of organized economic interests. In addition to the bankers' association representatives, manufacturers' associations, farmers' organizations, and trade unions select and send their own representatives to the committee. In this proposed advisory committee, the interests are broader than just those of the bankers and big capitalists, whose interests dominate the economic government; each interest is given "equal bargaining power." The interests involved are those being influenced by the policies of the FRB. The committee makes a "recommendation" to the FRB regarding its rules and its ways of executing those rules, developed through negotiations and compromise of the interests of the committee. In light of his description of other advisory committees (of the Wisconsin Industrial Commission) seen in his other work (Commons 1934b, p. 848), the FRB is to comply with the recommendation and "order" or perform it. A part of sovereign power-that is, the authority for making rules and executing them within a certain jurisdiction-is handed to the FRB, with the involvement of the committee given strong authority. Thus, the this involvement is interpreted as the governance system of the debt market, placed in the boundary area between the political and economic governments (see Figure 3). The governance system proposed by Commons is interpreted as a boundary system in the gap between political and economic governments.

Figure 3. The advisory committee as the boundary system between political and economic governments

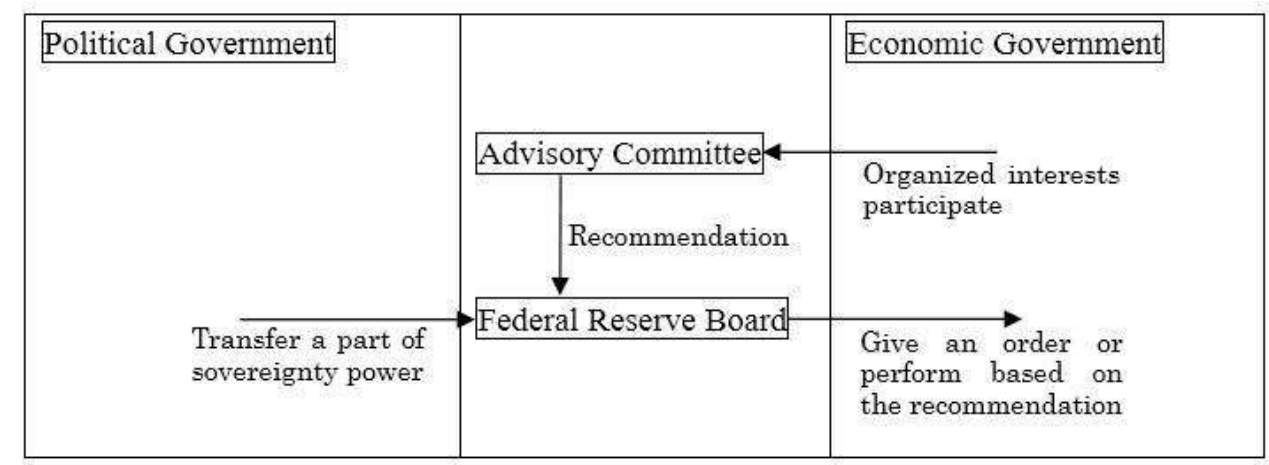

Source: Compiled by the author

\subsection{The Proposition Considering Ethical and Economic Principles}

When he proposed the advisory committee, Commons considered both ethical and economic principles. First, I analyze his proposition from the perspective of the political government and ethical principles. The merit of the proposition for the political government is to prevent dysfunction brought by the concentration on resolving 
frequent conflicts. Under the proposition, the economic interests directly negotiate their own economic conflicts and reach a compromise in the committee. From the perspective of the ethical principles, I can point to the following two. First, in the system, the bargaining powers of interest groups are intentionally equalized. Second, rules made by negotiation and compromise of the parties concerned have the potential to become better rules than those constructed by the political government. As noted above, when the political government makes its rules, its targeted level is a tradition of "ordinary" (Commons 1934b, p. 860). Ordinary has the same meaning as "reasonable" in the courts. However, the negotiation between interest groups has the possibility of constructing a rule that brings others up, as near as possible, to level of "best practicable" (Commons 1934b, p. 860-861). This is another meaning of "reasonable," constructed by the boundary system. The committee has the ability to diffuse higher levels of reasonable practices over its jurisdiction than do the courts.

Next, I analyze his proposition from the perspective of the economic government and economic principles. According to Commons (1950, p. 254-255), the expected profit margin involves a degree of "political confidence"; that is, one's expectation as to what degree the future policies of the political government are favorable for him/her. From the perspective of political confidence, the administration of the debt market by the political government brings a "lack of confidence" of bankers and big businesses. The lack of confidence means a reduction in the expected profit margin, which reduces industries' borrowings; that is, it reduces credit creation. On the other hand, the administration of the debt market by the economic government may excessively increase the expected profit margin, causing industries to excessively borrow funds, and speculate. As a consequence, credit creation increases and prices of commodities and securities rise, and the economic situation ends in a "collapse" (Commons 1950, p. 255). For the economic government, the advisory committee is evidently not favorable compared to their monopolized administration of the debt market. Yet on a long-term basis, this is not necessarily true. If we remember the experience of the Great Depression, where intense competition between bankers resulted in them facing catastrophic effects through the collapse of credit, the advisory committee is not necessarily an unfavorable system for them on a long-term basis.

Thus, Commons' proposition considered both the political and economic governments. If the governance system is adopted, then the degree of political confidence in the economic government is not as good, but not "lacking." While Commons himself did not say it clearly, this middle circumstance of political confidence is probably a good condition for the purpose of stabilizing money as a debt system.

\section{Conclusion}

57 If modern institutionalists start to construct "monetary institutionalism," they (we) should give some time and effort to excavating the materials of unacknowledged antecedents. With this motivation, this study examines the evolutionary monetary institution theory of J.R. Commons, and reconstructs it from his own contradictory concepts of political government (sovereignty) and economic government (private pay community). 

evolution of sovereignty and the pay community, and we can see the two processes of the co-evolution. One is the process where the political government has imposed regulations on the pay community based on ethical principles. The other is the process where the economic government, part of whose foundations are the laws of the political government, have endeavored to direct the political government toward the goal of its economic principles. These processes are similar to the two models shown by Dutraive and Théret (2017). However, this study went further by integrating the two parallel processes in the evolution of capitalistic institutions. My interpretation is that the heterogeneity of the governments or principles are two driving forces of constant change in the institutions and their simultaneous relationships of "mutual dependence," "conflict," and "politics."

From the perspective of two governments, I then confirm that Commons made a novel recommendation, suggesting that this recommended system go beyond the dichotomy of two governments. This recommendation is not a romantic ideal because he was concerned with both economic and ethical principles.

Nearly 80 years after the 1929 Great Depression, we experienced a world financial crisis, which was the emergence and collapse of securitized debts. Though the world economy seems to have recovered superficially, the great challenge of how we reconstruct the governance system to stabilize the debt market remains up in the air. Should we leave the role of the administrator to the political government or the economic government? Commons proposed an alternative-breaking away from the dead end of the dichotomy. His proposition-the advisory committee-is a boundary system in a gap between the political and economic governments. It may be a useful idea when we think about a novel governance system for money.

\section{BIBLIOGRAPHY}

Atkinson G. \& T. Oleson Jr. (1998), “Commons and Keynes: Their Assault on Laissez Faire”, Journal of Economic Issues, 32(4), p. 1019-1030.

Baslé M., (2002), “Acknowledged and Unacknowledged Institutionalist Antecedents of Régulation Theory”, in R. Boyer \& Y. Saillard (eds), C. Shread (tr.), Régulation Theory: The State of the Art, London and New York, Routledge. (Original book is Théorie de la régulation. L'état des savoirs, Paris, La Découverte, 1995).

Chernow R., (1990), The House of Morgan: An American Banking Dynasty and the Rise of Modern Finance, New York, Grove Press.

Commons J.R. (1924), The Legal Foundations of Capitalism, New York, Macmillan.

Commons J.R. (1927), Reasonable Value: A Theory of Volitional Economics, Manuscript from a collection of the Kyoto Prefectural Library. Call mark: /331.04/C85/, Material code: 1102508007. 
Commons J.R. (1928a), "Statements and Remarks before the Committee on Banking and Currency", in Committee on Banking and Currency, House of Representatives, Stabilization, Washington, D.C., United States Government Printing Office, p. 56-104, p. 423-445.

Commons J.R. (1928b), “Reasonable Value: A Theory of Concerted Action”, in H.L. Miller (ed.) (1986), Wisconsin Progressives, The John R. Commons Papers, Microfilm Edition, Madison, The State Historical Society of Wisconsin.

Commons J.R. (1929), "Jurisdictional Disputes”, in O.S. Beyer et al. (eds), Wertheim Lectures on Industrial Relations, 1928, Cambridge, Mass., Harvard University Press, p. 93-124.

Commons J.R. (1934a), Myself, New York, Macmillan.

Commons J.R. (1934b), Institutional Economics. Its Place in Political Economy, New Brunswick and London, Transaction Publishers.

Commons J.R. (1950), The Economics of Collective Action, New York, Macmillan.

Commons J.R. (1965), A Sociological View of Sovereignty (1899-1900), with an Introductory Essay "John R. Commons' General Theory of Institutions" by Joseph Dorfman, New York, A.M. Kelley.

Dutraive V. \& B. Théret (2013), “Seiji-Syuken To Kahei-Syuken: Commons No Chosaku Karano Ichi-Kousatu (Political Sovereignty and Monetary Sovereignty: An Interpretation Based on the Works of J.R. Commons)", Keizai-Ronso (The Economic Review), 187(1), p. 83-110.

Dutraive V. \& B. Théret (2016), Two Models of Monetary Sovereignty: An Interpretation based on J.R. Commons' Institutionalism. Paper for Monetary Institutionalism in the French-Speaking World: Past Record, Future Prospects and International Perspectives. 2 June 2016, Session D2, Lyon, Sciences Po Lyon.

Dutraive V. \& B. Théret (2017), “Two Models of the Relationship between Money and Sovereignty: An Interpretation Based on John R. Commons's Institutionalism”, Journal of Economic Issues, 51(1), p. 27-44.

Kitagawa K. (2017), “Two Methods of Institutional Reform in the Institutional Economics of John R. Commons", in H. Uni (ed.), Contemporary Meanings of J.R. Commons's Institutional Economics: An Analysis Using a Newly Discovered Manuscript. Singapore, Springer, p. 73-98.

Nakahara T. \& H. Uni (2016), “Monetary Institutionalism in J.R. Commons’ Institutional Economics: Sovereignty and Money as Grand Institution Mediating ‘Engineering Economy' and 'Proprietary Economy"'. Paper for Monetary Institutionalism in the French-Speaking World: Past Record, Future Prospects and International Perspectives. 2 June 2016, Session D2, Lyon, Sciences Po Lyon.

Tymoigne E. (2003), “Keynes and Commons on Money”, Journal of Economic Issues, 37(3), p. 527-545.

Weber M. (1919), Politik als Beruf, Leipzig, Duncker \& Humblot, München, translated by T. Waters \& D. Waters (2015), Politics as Vocation, in T. Waters \& D. Waters (eds), Weber's Rationalism and Modern Society, New York, Palgrave Macmillan.

Whalen C.J. (1993), "Saving Capitalism by Making It Good: The Monetary Economics of John R. Commons", Journal of Economic Issues, 27(4), p. 1155-1179.

Whalen C.J. (2008), "John R. Commons and John Maynard Keynes on Economic History and Policy: The 1920s and Today", Journal of Economic Issues, 42(1), p. 1155-1179. 
Wicksell K. (1898), Geldzins und Güterpreise: Eine Studie über die den Tauschwert des Geldes bestimmenden Ursachen, Jena, Gustav Fischer, translated by R.F. Kahn (1936), Interest and prices: A Study of the Causes Regulating the Value of Money, London, Macmillan.

\section{NOTES}

1. This aspect is the same as M. Weber's famous definition of state (Weber 1919). However, the second aspect, sovereignty as a process, may be the interesting point of Commons' discussion. As a process, as shown in Commons $(1924,1934 b, 1965)$, sovereignty co-evolves with the economy. This perspective of sovereignty is the uniqueness of Commons' perspective, and Dutraive and Théret (2017), therefore, stressed this perspective.

In regard to physical force or violence, the concept of sovereignty is connected with the monopolization of violence. The only authority administering violence is the state. However, this does not mean the state-in this paper, the political government-does not use economic and cultural powers. In reality, as Commons (1950, p. 77, p. 214) briefly said, the political government also uses economic and cultural sanctions, and sometimes a sanction is the combination of violence and the other two powers.

2. In Commons (1934b, p. 512-513), unlike in the quantity theory of money, PT (P: prices of trade, $\mathrm{T}$ : volume of trade) is decided by not MV (M: quantity of money, V: velocity of money), but by the expectation of obtaining a profit margin. This expectation drives business persons to borrow from banks. This borrowing before profit is realized creates effective demand. Therefore, customary and legal controls of these expectations is an important issue for Commons (1934b). As discussed in section 4, the expectations contain political confidence. It is one of the reasons that Commons presented his novel governance institution for the debt system.

3. The unit of validity correlates the transaction of goods with creation of debt. Under a certain unit of validity, a price in a commodity market decides the size of debt created in the debt market. In other words, the unit of validity correlates the commodity market with the debt market.

4. As shown in Commons (1934b, p. 242), sovereignty is the underlying "fifth party" of each bargaining transaction.

5. According to Commons (1934b, p.560-590), large swings in corporations' narrow profit margins cause instability in modern capitalism.

6. The approach of the Federal Reserve Board is to control the discount rate, and the reserve ratio (Commons 1934b, p. 610).

7. Commons (1934b, p. 6) expressed the three circumstances of transactions: "conflict," "mutual dependence," and "order." I interpret the first two concepts as expressing the parallel relationships between political and economic governments. The other term I use in section 3.3., "politics," is, according to Commons, the process of negotiation and compromise of participants in a transaction to get further power. The compromise, a result of politics, is the circumstance of "order," the third concept, which means that the behaviors of participants involved in the compromise become institutionalized.

8. The Federal Reserve System is nonetheless not completely the policy tool of the political government. It is the amalgam of political and economic governments.

9. The congress and executive branches are organizations that do not merely behave based on ethical principles. There are also arenas of "politics," mentioned below, based on the principle of the "struggle for power" (Commons 1934b, p. 761). Yet, if their laws and administration run counter to the ethical principles of that time and place, in the end, the Supreme Court will deem them unconstitutional. In this way, the Congress and executives are also (in an indirect way) based on strong ethical principles. Therefore, in the United States' system of “judicial 
sovereignty," it may be said that the political government is ultimately subjected to ethical principles.

\section{ABSTRACTS}

This article clarifies the evolutional theory of money as an institution presented by the American institutionalist J.R. Commons, from the perspective (dichotomy) of the political government ("sovereignty") and the economic government (the alliance between the pay community and industry). This article identifies two interactive processes between the political and economic governments, and integrate them to present a constant evolution driven by mutual dependence, conflict, and the politics of these governments. Finally, it places Commons' proposition of an "advisory committee," a novel governance system of the debt market, as a boundary system in the gap between the governments.

INDEX

Keywords: J.R. Commons, sovereignty, political government, economic government, advisory committee

\section{AUTHOR}

\section{KOTA KITAGAWA}

Associate Professor, Faculty of Economics, Kansai University. E-mail: kota.k@kansai-u.ac.jp 